Article

\title{
Analysis of the Structure and Use of Digital Resources on the Websites of the Main Football Clubs in Europe
}

\author{
Santiago Tejedor ${ }^{1, *}$, Laura Cervi ${ }^{1}$ and Gerard Gordon ${ }^{2}$ \\ 1 Department of Journalism and Communication Sciences, Universitat Autonoma de Barcelona, \\ 08193 Bellaterra, Spain; laura.cervi@uab.cat \\ 2 Department of Communication, Universitat Abat Oliva CEU, 08022 Barcelona, Spain; gerardgg1@gmail.com \\ * Correspondence: santiago.tejedor@uab.cat; Tel.: +34-93-581-15-45
}

Received: 24 January 2019; Accepted: 10 April 2019; Published: 29 April 2019

\begin{abstract}
Football clubs can be considered global brands, and exactly as any other brand, they need to face the challenge of adapting to digital communications. Nevertheless, communication sciences research in this field is scarce, so the main purpose of this work is to analyze digital communication of the main football clubs in Europe to identify and describe what strategies they follow to make themselves known on the internet and to interact with their users. Specifically, the article studies the characteristics of web pages-considered as the main showcase of a brand/team in the digital environment—of the fifteen best teams in the UEFA ranking to establish what type of structure and what online communication resources they use. Through a descriptive and comparative analysis, the study concludes, among other aspects, that the management of communication is effective, but also warns that none of the analyzed team takes full advantage of the possibilities of interaction with the user offered by the digital scenario.
\end{abstract}

Keywords: football; clubs; webs; digital communication; marketing; engagement

\section{Introduction}

Sports have a huge influence in our current society: sport activities occupy an important percentage of people's leisure, becoming both economically and culturally crucial. As the Baron de Coubertin affirmed, "It is a fundamental part of the inheritance of [many]" [1].

Back in 2006, a study of the European Union suggested that, on the one hand, $60 \%$ of European citizens actively practice a sport and, on the other, that sport in Europe moves around 407 billion euros, which means $3.7 \%$ of EU GDP and employs 15 million people, equivalent to $5.4 \%$ of the labor force [2].

With more than 200 million active players, football has become one of the most lucrative leisure industries.

Nowadays, FIFA, the International Federation of Football Association (Fédération Internationale de Football Association), the governing body of football federations, has marked the milestone to increase the "participation of more than $60 \%$ of the world's population-whether as a player, coach, referee or in any other role-in the world of football" [3] by the 2026 World Cup.

For this reason, many authors have described football as the final stage of the current globalization process [4-7]. If globalization can be defined as the historical process of global integration of the political, economic, social, cultural and technological fields, which has made the world an increasingly interconnected place [5], then football is a clear example of globalization. Accordingly, Boniface points out that football is the "first truly global empire and, unlike others, it has spread throughout the planet in a peaceful way and without the need to impose itself" [5].

Until the early Nineties, football represented a local, national or continental issue, being one of the most protected sectors of the economy, since European teams could only hire a limited number 
of foreign players (normally three per team), but, in 1995, the "Bosman trial" changed the history of this sport by transforming the richest teams into transnational companies [8]. The free movement of players and the disappearance of the quotas of foreigners, allowed the richest teams of the richest championships (English Premier League, German Bundesliga, Spanish Liga, Italian Serie A and French League) to hire the best players in the world, regardless of their nationality. Proni andand Zaia [9] suggest that, in many rich countries, where market economy dominates the sports scene, football has become a product, transforming some teams into actual global brands with followers all over the world.

This alliance between leisure and business, between sport, show and millionaire profits, cannot be explained without mentioning the massive investment in advertising and mediated sports performance [10]. In other words, the development of technologies, in primis television technologies, which allow to live the show of football without having to leave the sofa, have transformed this sport into a mass spectacle. The economic balance of FIFA perfectly illustrates this synergy: the organization, during the year 2015, gained 1,152 million dollars for the organization of tournaments, sales of television broadcast, etc [3].

Summing up, "the transformation of television and the globalization of sport have multiplied mutual economic interests" [11], generating relationships of "symbiosis and parasitism" [12], between actors: sports organizations, commercial organizations and communication groups. The advance in communication technologies, especially digital and satellite television, and subsequently the internet and smartphones [13], have allowed football to acquire a constant and global presence.

In other words, the Digital Revolution and the emergence of Information and Communications Technologies, represent the main challenge for companies and institutions [14], that have to redefine their business model and adapt to these changes [8].

The acronym ICTs, Information and Communications Technologies once used to refer to the convergence of audiovisual and telephone networks, nowadays covers any product that will store, retrieve, manipulate, transmit, or receive information electronically in a digital form [15].

In relation to this, Boyle and Hayes [13] emphasize that sports organizations increasingly try to avoid media control of the messages they broadcast, generating their own communication media, such as television channels and/or internet or mobile marketing applications, which allow them to generate content directly for users.

As we will discuss in the theoretical framework, the study of football communication in the digital environment is quite extended in different disciplines, mostly marketing and sports disciplines [16-18] communication research on this topic, specifically on corporate webpages, is scarce [19]

The study of the corporate portals of the media has been extended to other types of projects and instances [20] of the business, cultural and economic sphere, among others. The works of Ellcelssor [21], Codina et al. [22] have influenced the need to analyze the uses of these web pages. Authors such as Giomelakis and Veglis [23] and Costa-Sánchez and Guarinos Galán [24] have highlighted the importance of assessing a corporate brand, studying its website. In this sense, beyond the digital ecosystem generated by the networks and the set of social platforms, the challenge is to study the role played by the main page or corporate website, conceived as the main information space and as a primary and reference point in the communicative process of an institution, project or organization. Web pages are, thus, considered the embryonic core and the point of reference of the set of digital communication actions that, practically in all cases, lead to this website.

The aim of this study is, therefore, to analyze what strategies main football clubs in Europe use to make themselves known in the cyberspace and interact with their users through their webpages.

The article analyzes the characteristics of web pages-considered as the main showcase of a brand/team in the digital environment-of the fifteen best teams in the ranking of the Union of European Football Associations (UEFA). Based on the above, the article responds to the following research questions with a descriptive scope: "What kind of structure and online communication resources are used by the main football clubs in Europe on their web pages?". In relation to it, 
and considering the findings of Yoshida, Gordon, Nakazawa and Biscaia [25] about users' engagement, together with Verónica Baena's research [26] on Real Madrid, the following working hypotheses have been considered:

H1. Soccer clubs in general, tend to choose a very simple web structure that mainly promotes corporate information.

H2. The websites design is set up in order to differentiate the club and to emphasize the idiosyncratic elements of each of the clubs.

H3. The websites do not fully exploit the possibilities that the digital environment offers them.

\section{Theoretical Framework}

\subsection{Sports and ICTs}

The study of sport is, by definition, multidisciplinary. The interest of the social sciences for sport as a research phenomenon is quite recent; traditional university research took a while to start studying it [1]. Probably, for this reason, sociology—the first discipline that was scientifically interested in sport-both in Anglo-Saxon and Spanish countries [27,28], has long prioritized researches about negative aspects, such as, for example, the association between football and violence. This trend, and the negative connotations given to sport, begun to change progressively in the 70s. In the 90s, football begun to be studied from an economic perspective -for obvious reasons related to the sports industry- and finally as a cultural manifestation and as an agent of social aggregation or reinforcement of identities.

Since then, the interest in sports and precisely football, as an object of study in the field of communication, especially in media studies, has not stopped growing [10]. However, as mentioned above, although there is an extensive bibliography on media and football, especially regarding the image and information that is disseminated through the media, few publications focus on external communication strategies. In addition, most of the works addressing this issue, rarely do so from the digitalization and, specifically, from the analysis of the digital ecosystem perspective [29].

\subsection{Marketing and ICTs}

Giulianotti [28] states that the goal of sports communication is to transform fans into loyal consumers. The bibliography on football fans is very extensive. In fact, the symbolic nature of football facilitates and enhances the identification with a collective group and the representation of abstract values, such as a brand image. On the one hand, there is a wide sociological tradition that investigates the relationship between soccer teams and followers based on their ability to create identities. Authors, such as Bordieu [30], emphasize that football perfectly captures the notion of imagined community and that imagined communities become more real in the stadium, Hobsbawm [31] demonstrates the ability of this sport to invent traditions that tend to identify the stadium as a mythological place that facilitates the sense of collective identification. Roversi [32] goes so far as to affirm that the fans do not actually support a team but a place, so that the success of their team is synonymous with the success of a place. Nevertheless, these observations do not take into account the aforementioned global dimension of the teams that have followers all over the world as pointed out by Yoshida, Gordon, Nakazawa and Biscaia [25], among others.

In relation to this, taking FC Barcelona as an example, it is likely that for a Catalan follower, Barça will be "more than a club" (in the political identity sense), but the same cannot be said of all those fans located in other countries or continents. Probably, the latter will know very little, to say nothing, about this dimension and will not even be very interested. In this sense, Bale [33] recognizes that football represents a powerful mean of collective identification with a place, but also serves to project a place to people who otherwise would not have known it. Therefore, other authors have devoted themselves to the study of the follower of this sport as a consumer. Moragas [34], for example, highlights the 
difference between the consumer of sport and the consumer of other products, emphasizing that the followers of sport clubs develop a blind loyalty to their team that helps them not to leave it aside even when the results are not positive. In the words of Roberts [35], they generate a "loyalty beyond reason".

By contrast, Ferran Soriano [36], former economic vice president of FC Barcelona, openly criticizes this paradigm stating that the team is the product and if there is no product [the team does not meet the expectations of the fans] marketing or any other actions become completely useless.

According to Yoshida, Gordon, Nakazawa and Biscaia [25], sport fans generate unique behavioral responses.

Based on this, it is quite evident that a football clubs shares with any other company the challenge of adapting their communication to the digital environment. This becomes evident observing Table 1, which shows the increase in sport advertising investment in Europe.

Table 1. Advertising investments.

\begin{tabular}{|c|c|c|c|c|c|}
\hline Media & 2013 & 2014 & 2015 & Increase & 2016 \\
\hline TV & $1.703,4$ & $1.890,4$ & $2.011,3$ & $5.5 \%$ & $2.121,6$ \\
\hline Digital & 960,1 & $1.065,6$ & 1288,9 & $21.5 \%$ & $1.565,6$ \\
\hline Newspapers & 662,9 & 656,3 & 658,9 & $-6.3 \%$ & 617,4 \\
\hline Radio & 403,6 & 420,2 & 454,4 & $0.8 \%$ & 458,0 \\
\hline Posters & 282,0 & 314,7 & 327,4 & $-2.0 \%$ & 321,0 \\
\hline Magazines & 254,9 & 254,2 & 255,2 & $-1.2 \%$ & 252,2 \\
\hline $\begin{array}{c}\text { Sunday } \\
\text { Newspapers }\end{array}$ & 38,7 & 37,7 & 37,8 & $-10.6 \%$ & 33,8 \\
\hline Cinema & 20,2 & 16,2 & 22,0 & $2.7 \%$ & 22,6 \\
\hline Total & $4.324,8$ & $4.655,3$ & $5.055,9$ & $8.6 \%$ & $5.392,5$ \\
\hline
\end{tabular}

Source: La Vanguardia, adapted by the authors.

Both communication sciences, and social sciences, such as sociology, and economic disciplines, especially marketing, have understood that the paradigm of communication has changed with the appearance of new technologies, which allow users to be connected at all times [29] to get a potentially infinite amount of information and interactions. Jenkins (2015) states that Web 2.0 has become a kind of cultural dynamic that encompasses any digital business with the aim of capturing and exploiting the participatory culture [37]. Costa and Piñeiro [38] emphasize that the impact of interactivity in narrative transforms the traditional storytelling techniques in favor of a horizontal, collaborative and social dialogic logic.

In this context, marketing has invented a new word that summarizes all these concepts: prosumer. The word prosumer is an acronym that comes from the merger of two words: "producer" and "consumer". The concept, anticipated by McLuhan and Nevitt [39], and disseminated by Levine, Locke, Searls and Weinberger [40], refers to the fact that electronic technology allows the consumer to simultaneously assume the roles of producer and consumer of content. This new scenario, somehow forces organizations to opt for the resource of conversation, understanding cyberspace as a context endowed with a great capacity to multiply intellectual capital. In this way, it is key to establish a new communicative relationship between sender and receiver, since the user ceases to be a passive testimony of the information to be an actor and participate in this communicative act [41].

In response to this trend, digital corporate communication emerges, which encompasses the set of actions necessary to advertise the activity of the organization on the Web and, in particular, to satisfy the demand of what the different publics want [42]. Its main objective is to get more users on the website or, in other word, generate loyalty and engagement [43].

The concept of engagement has been recently defined as a set of behavioral manifestations of the client towards the company (commitment and loyalty, mainly) above the mere purchase action that occurs as a result of individual motivations. These behaviors can be defined non-transactional 
and are especially valuable for companies because, although they do not generate immediate income, they improve their image and influence on long-term consumers. In other words, everything it is based on getting the largest possible number of users to share the published content, thus creating a network of influences based on the amount of "likes", visualizations or the specific metric of the platform, depending on the type of material and the platform used.

Studies like those of Ioakimidis [15], Araujo et al. [17], Baena [18] have investigated the impact of dialogical platforms, digital marketing or mobile telephony in the sports arena. However, the study of corporative website as the main unit of information, communication and interaction, has been given scarce importance and prominence.

Nevertheless, UEFA's Club Licensing Benchmarking Report of 2016, underlines that clubs that generate the most visitors to their websites tend to have a broad reach that encompasses their domestic market and other global markets [44].

Accordingly, our research will focus on web pages, understood as the main information space and the primary and reference point in the communicative process of an institution [22].

\section{Method}

Based on the above, our research analyzes, using descriptive and comparative methods, the digital ecosystem of the fifteen major football clubs in Europe, focusing on the detailed study of their web pages. Clubs have been selected according to UEFA's (Union of European Football Associations) ranking, listing the best clubs in Europe for their performance over the last five seasons, acknowledging that the best performing clubs may not be the clubs with the highest amount of followers/traffic.

The selected teams, as shown by Table 2, are: Real Madrid CF (Spain), FC Bayern München (Germany), FC Barcelona (Spain), Club Atlético de Madrid (Spain), Juventus (Italy), Paris Saint-Germain (Paris), Borussia Dortmund (Germany), Sevilla CF (Spain), SL Benfica (Portugal), Chelsea FC (England), Arsenal FC (England), Manchester City FC (England), FC Porto (Portugal) and Manchester United FC (England).

Table 2. Club sample.

\begin{tabular}{ccccc}
\hline $\begin{array}{c}\text { Real Madrid CF } \\
\text { (Spain) }\end{array}$ & $\begin{array}{c}\text { FC Bayern } \\
\text { München } \\
\text { (Germany) }\end{array}$ & $\begin{array}{c}\text { FC Barcelona } \\
\text { (Spain) }\end{array}$ & $\begin{array}{c}\text { Club Atlético de } \\
\text { Madrid (Spain) }\end{array}$ & Juventus (Italy) \\
\hline $\begin{array}{c}\text { Paint-Germain } \\
\text { (France) }\end{array}$ & $\begin{array}{c}\text { Borussia } \\
\text { Dortmund } \\
\text { (Germany) }\end{array}$ & Sevilla FC (Spain) & $\begin{array}{c}\text { SL Benfica } \\
\text { (Portugal) }\end{array}$ & Chelsea FC (UK) \\
\hline Arsenal FC (UK) & $\begin{array}{c}\text { Manchester City } \\
\text { F.C. (UK) }\end{array}$ & FC Porto (Portugal) & $\begin{array}{c}\text { FC Schalke 04 } \\
\text { (Germany) }\end{array}$ & $\begin{array}{c}\text { Manchester United } \\
\text { FC (UK) }\end{array}$ \\
\hline
\end{tabular}

Source: elaborated by the authors.

\section{Analysis of the Webpages}

In order to classify and describe the different components of the main digital platform (website) of each of the analyzed club, we have created a four level framework, taking into account home page, header and bottom frame, and the typology and design of the contents published on the website.

Our framework, displayed in Table 3, is adapted from the proposal of Rodriguez-Martinez, Codina, and Pedraza-Jiménez [45], based on Landow's [46] classic model of hypertext analysis. 
Table 3. Level of the analysis.

\begin{tabular}{cl}
\hline Level 0: General information & $\begin{array}{l}\text { This level assess the basic information of the club. Specifically, the existence of a web page, } \\
\text { the number of languages of the contents offered and the type of domain used. }\end{array}$ \\
\hline Level 1: Superior frame or header & $\begin{array}{l}\text { This level of analysis collects information on the header of the page focusing on whether } \\
\text { the club has other sports sections, if there is a search option on the menu, if it offers the } \\
\text { chance to register to have exclusive content and if there is a virtual store. }\end{array}$ \\
\hline Level 2: Type and content design & $\begin{array}{l}\text { This level analyzes in detail, from a descriptive approach, the information of the articles, } \\
\text { such as elements of title, type and presence of multimedia content, use and type of } \\
\text { hyperlinks. In addition, the possibility of interaction of Internet users is also assessed, as } \\
\text { well as other information relevant to the user's browsing experience. }\end{array}$ \\
\hline Level 3: Inferior Frame & $\begin{array}{l}\text { This level analyzes the bottom frame of the page: the sponsors of the club, the access to } \\
\text { social networks, the type of physical design of the template and the structure of the } \\
\text { navigation menu. }\end{array}$ \\
\hline
\end{tabular}

Source: elaborated by the authors.

\section{Results}

Although nowadays the most important source of communication are social networks, the study has established that most of the messages broadcasted by clubs originate on their official website. Specifically, the study establishes that the clubs mostly use the contents of their website to feed the contents of all the platforms that make up their respective digital ecosystems.

In this section, we will present the main results, classified by different categories or thematic areas:

Plurality of languages. Clubs are not only known in their country of origin, since as global brands they have followers around the world. Therefore, they face the need to reach a greater number of countries. The translation of the content into several languages is thus fundamental, and there are differences in the number of languages used by the websites. Specifically, as shown by Figure 1, clubs offer an average of six languages: only four teams do not reach this number of translations (Oporto, Arsenal, Benfica and Atlético de Madrid), an aspect that affects its territorial scope compared to the rest.

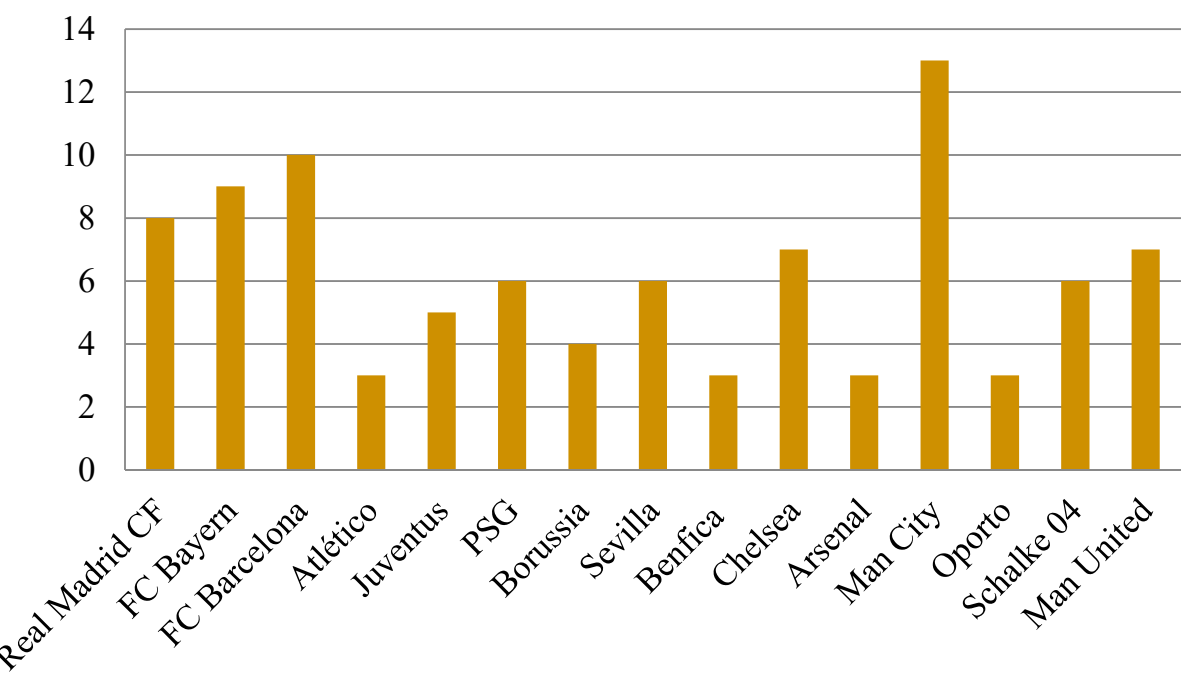

Figure 1. Number of languages available in the webpages. Source: Elaborated by the authors.

Distribution of the header. Table 4 shows that there is a predominance of the use of the horizontal bar with the section keypads with several options to navigate. The registration and login options are located in the upper right, next to the search button. These last two options are present in $80 \%$ of the clubs analyzed and only one of them (FC Oporto) does not have a store option on the menu. It is also common to see a clear distinction between the navigation menu and the menu for selling club products (or merchandising line). 
Table 4. Distribution of the header.

\begin{tabular}{|c|c|c|c|c|c|c|c|}
\hline & Sections & Search Engine & Registration & Store & Social Networks & Pattern & E-Commerce \\
\hline Real Madrid & Yes & Yes & Yes & Yes & No & No & Yes \\
\hline FC Bayern & No & Yes & Yes & Yes & No & No & Yes \\
\hline Atlético & Female & Yes & Yes & Yes & Yes & No & No \\
\hline Juventus & No & Yes & Yes & Yes & No & No & No \\
\hline Borussia & No & Yes & Yes & Yes & Yes & Yes & No \\
\hline Sevilla & Female & Yes & No & Yes & No & No & No \\
\hline Benfica & Yes & Yes & Yes & Yes & In the menu & No & No \\
\hline Chelsea & Female & Yes & Yes & Yes & No & No & No \\
\hline Schalke 04 & Yes & Yes & No & Yes & Yes & No & No \\
\hline Man United & no & Yes & Yes & Yes & Yes & no & no \\
\hline
\end{tabular}

Source: Elaborated by the authors.

Moreover, only five teams, Atletico, PSG, Sevilla, Chelsea and Arsenal dedicate a space to the so-called "female section", that is to say the female team.

Extension of the domain. Figure 2 shows that $66.7 \%$ of the clubs opt for the .com domain to reach a more global community, because it is a generic superior domain, while the rest use the territorial domain of their country of origin. In this group, we must highlight the case of Fútbol Club Barcelona, whose first option of viewing is under the .cat domain, typical of Catalonia, although it also has others depending on the user's location.

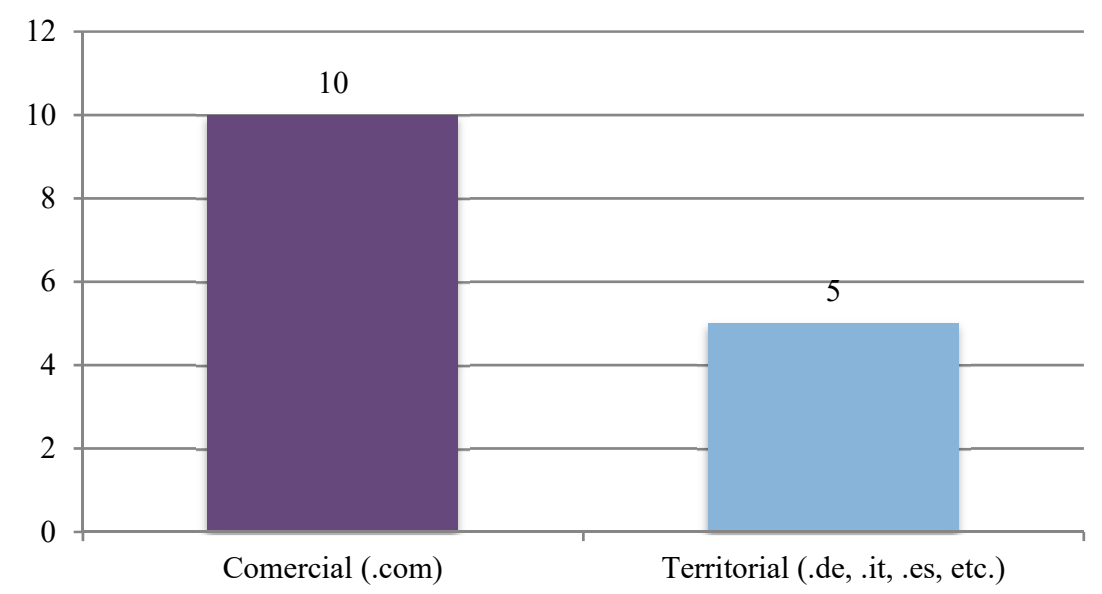

Figure 2. Domain extension. Source: elaborated by the authors.

Content design. The distribution of content is based on a structured pattern with news highlighted with bigger fonts. In addition, it is important to mention that $40 \%$ of the teams have advertising on their website, a fact that can impoverish user experience and increase the rate of abandonment of the platform.

Table 5 shows the content design. The category "Title" takes into consideration whether the page has only the Tile (1), a Pre-Tile (2) or also a Subtitle (3). 
Table 5. Content design and type.

\begin{tabular}{ccccccccc}
\hline & Titles & Images & Videos & Figures & Links & Context & Enlargement & Concept \\
\hline Real Madrid CF & 1,3 & Yes & Yes & No & Yes & No & Yes & Yes \\
\hline FC Bayern & $1,2,3$ & Yes & Yes & No & No & No & No & No \\
\hline FC Barcelona & 1 & Yes & Yes & No & Yes & Yes & Yes & Yes \\
\hline Atlético & $1,2,3$ & Yes & Yes & No & Yes & Yes & Yes & Yes \\
\hline Juventus & 1 & Yes & Yes & No & Yes & No & Yes & No \\
\hline PSG & 1 & Yes & Yes & No & Yes & No & Yes & No \\
\hline Borussia & 1 & Yes & Yes & No & Yes & No & Yes & No \\
\hline Sevilla & 1 & Yes & Yes & No & Yes & No & Yes & No \\
\hline Benfica & 1,3 & Yes & Yes & No & No & No & No & No \\
\hline Chelsea & 1,3 & Yes & Yes & No & Yes & No & No & Yes \\
\hline Arsenal & 1,3 & Yes & Yes & No & Yes & Yes & Yes & Yes \\
\hline Manchester City & 1 & Yes & Yes & No & Yes & Yes & Yes & Yes \\
\hline Oporto & 1 & Yes & Yes & No & No & No & No & No \\
\hline Schalke 04 & $1,2,3$ & Yes & Yes & No & Yes & No & No & Yes \\
\hline $\begin{array}{c}\text { Manchester } \\
\text { United }\end{array}$ & 1 & Yes & Yes & No & Yes & \multirow{2}{*}{ No } & Yes & \multirow{2}{*}{ No } \\
\hline & & \multicolumn{2}{c}{ Source: elaborated by the authors. } & &
\end{tabular}

Use of multimedia and interactive resources. The study concludes that all the clubs analyzed offer a great variety of images and videos, as well as links to other news sources in their web pages. However, as shown by Table 6, none of the clubs allows users to actively interact (through comments or other dialogical channels).

Table 6. Use of multimedia and interactive resources.

\begin{tabular}{ccccccc}
\hline & Advertising & Audio & List & \multicolumn{2}{c}{ Interactivity } & \multicolumn{2}{c}{ Social Networks } & \multicolumn{2}{c}{ Newsletter } \\
\hline Real Madrid CF & Yes & No & No & No & Yes & Yes \\
\hline FC Bayern & No & No & No & No & Yes & Yes \\
\hline FC Barcelona & Yes & No & No & Indirect & Yes & Yes \\
\hline Atlético & Yes & No & Yes & No & Yes & Yes \\
\hline Juventus & Yes & No & Yes & No & Yes & Yes \\
\hline PSG & Yes & No & Yes & No & Yes & Yes \\
\hline Borussia & Yes & No & Yes & No & Yes & Yes \\
\hline Sevilla & Yes & No & Yes & No & Yes & Not official \\
\hline Benfica & Yes & No & Yes & No & Yes & Not official \\
\hline Chelsea & No & No & No & No & Yes & Yes \\
\hline Arsenal & No & No & No & No & Yes & Yes \\
\hline Man City & No & No & No & No & Yes & No \\
\hline Oporto & No & No & No & No & Yes & Yes \\
\hline Schalke 04 & No & No & No & No & Yes & Yes \\
\hline Manchester United & Yes & No & No & No & Yes & Yes \\
\hline & & Source: elaborated by the authors. & &
\end{tabular}

Link to social networks. Table 7 displays how most of the clubs redirect the content to generate a significant influx of visitors to the networks and thus obtain a greater number of followers. In this regard, it is worth mentioning that all clubs have a link to their complementary platforms on their website, but the position of these hyperlinks in the lower part of the page is preferable. Of the selected sample, $80 \%$ of the teams follow this premise, although there is $40 \%$ of it that includes it in the upper frame (so in some cases we can observe a repetition of links in both locations). 
Table 7. Design of the bottom frame.

\begin{tabular}{|c|c|c|c|c|}
\hline & Sponsors & Social Networks & Pattern & Menu \\
\hline Real Madrid CF & Yes & Yes & No & Yes \\
\hline FC Bayern & Yes & Yes & No & Yes \\
\hline FC Barcelona & Yes & Yes & Yes & No \\
\hline Atlético & Yes & Yes & No & No \\
\hline Juventus & Yes & Yes & No & No \\
\hline PSG & Yes & Yes & No & No \\
\hline Borussia & Yes & Yes & No & No \\
\hline Sevilla & Yes & Yes & No & Yes \\
\hline Benfica & Yes & Yes & No & No \\
\hline Chelsea & Yes & Yes & Yes & No \\
\hline Arsenal & No & No & No & No \\
\hline Manchester City & Yes & Yes & Yes & No \\
\hline Oporto & Yes & No & No & Yes \\
\hline Schalke 04 & Yes & Yes & No & No \\
\hline $\begin{array}{c}\text { Manchester } \\
\text { United }\end{array}$ & No & no & No & No \\
\hline
\end{tabular}

Source: elaborated by the authors.

\section{Conclusions}

In this section, we will comment on the formulated hypothesis.

H4. Soccer clubs generally choose a very simple web structure providing mainly corporate information.

The development of the contextual study on digital communication and presence on the Internet, together with the analysis carried out by the aforementioned clubs, makes it possible to determine that the management of communication is effective, but it can be improved in different way. In all cases, interaction should be emphasized, an aspect that has a decisive value to achieve a more important navigation at the user level. The most remarkable aspect of the analysis is that none of the teams offers elements of interaction, such as the option to comment on news or a "like" button, among other options. There are, however, elements of indirect interaction, as in the case of Arsenal, which collects tweets from fans in a sector of its website. Even so, this is very limited and web pages do not stop being one-way information portals, an aspect that does not allow enhancing the collaborative and participative essence of the cyberspace. Web pages satisfactorily collect the interests of the club in the form of news and general content for the fans. Some teams, such as Oporto FC, Schalke 04 or Benfica, present a web page of a shorter and simpler nature than that of the other teams. This aspect allows us to affirm that there is a correlation between the difference in importance and role of clubs and their digital communication, despite the fact that one of them is the club with the highest amount of members in Europe. Finally, and in line with what mentioned above, we underline the need for clubs to exploit the interaction with the user at a general level.

H5. The design of the websites denotes an effort to differentiate themselves and emphasize the idiosyncratic elements of clubs.

There are a number of common aspects that determine a clear pattern in most web pages, such as the predominance of club colors (the Real Madrid page is white, Barcelona's page is blaugrana, etc.), but there are those that break with this dynamic to be more original and distribute the information in another way. In Borussia Dortmund's web, for example, the menu bar of is in diagonal instead of the 
traditional horizontal position. It also has a clearly differentiated distribution of its cover contents, organized in two columns, while the rest of the teams dislay their content horizontally. Another relevant case is that of the two Manchester teams. First, the City distributes its content in in two columns, but unlike Borussia, these are independent. This aspect allows the user to surf through the left column as the main web page and, subsequently, through the column on the right where recent news, tweets and other data presented in a more dynamic way. Secondly, United presents a more disruptive system, since it leaves the traditional horizontal bar to place it on the left side of the page, in vertical position.

H6. Soccer clubs do not fully exploit the possibilities that the digital environment offers them.

According to our analysis, clubs opt for a set of valid multimedia strategies, such as the inclusion of videos, pictures or links to social networks that stimulate interaction and navigation through their website. Even so, cyberspace allows the inclusion of other types of resources beyond the audiovisual ones. The interactive and participative idiosyncrasy of the Network is not fully implemented.

In conclusion, we consider that, in order to increase engagement, clubs should implement a system of interaction, such as transmedia narrative and stories, since the exploitation of the multimedia and transmedia component is, for the moment, very limited.

\section{Discussion}

The study delves into the need to expand academic work around the convergence of areas of study such as communication, social networks and sports. Both 2.0 and 3.0 environment offer many possibilities yet to be discovered. At the communicative level, it would be interesting to foster the research on aspects such as transmedia narrative or storytelling, which could enrich the digital content and improve the user experience, as well as the interaction between follower and club through collaborative platforms and digital communication tools offered by cyberspace. In this same line of discussion, enhancing interaction would improve clubs' transparency and their (virtual) proximity with followers.

This aspect raises the need to abandon the traditional communication model and adapt to the current new paradigm, exploiting more innovative multimedia resources.

Author Contributions: Conceptualization, L.G. and S.T.; methodology, G.G.; software, G.G.; validation, S.T. and L.G.; formal analysis, G.G.; investigation, G.G.; data curation, S.T.; writing-original draft preparation, L.G.; writing-review and editing, L.G.; visualization, S.T.

Funding: This research received no external funding.

Conflicts of Interest: The authors declare no conflicts of interest.

\section{References}

1. Cervi, L. Identitat i Fútbol: El Clàssic Espanyol vist des d'Europa; Fundació Esport i Ciutadania, Pagès: Lleida, Spain, 2013.

2. European Commission. White Paper on Sport; Comissió Europea: Brusselles, Belgium, 2007.

3. FIFA. Informe de Finanzas y Gobernanza 2015, des de. 2016. Available online: http://resources.fifa. com/mm/document/affederation/administration/02/77/08/71/gb15_fifa_web_es_spanish.pdf (accessed on 22 December 2019).

4. Sebreli, J.J. La Era del Fútbol; Editorial Debolsillo: Buenos Aires, Argentina, 1998; ISBN 9789875660496. Available online: http://books.google.com.ar/books?id=RH7ewye6IcEC (accessed on 4 January 2019).

5. Boniface, P. La Terre est Ronde Comme un Ballon. Géopolitique du Football; Seuil: Paris, France, 2002.

6. Poli, R. L'Europe à Travers le Prisme du Football. Nouvelles Frontières Circulatoires et Redéfinition de la Nation. Available online: https://journals.openedition.org/cybergeo/2802 (accessed on 7 January 2019).

7. Milanovic, B. Globalization and goals: Does soccer show the way? Int. Econ. 2005, 12, 829-850. [CrossRef]

8. Lule, J. Globalization and Media: Global Village of Babel; Rowman \& Littlefield: Lanham, MD, USA, 2017. 
9. Proni, M.W.; Zaia, F.H. Gestão empresarial do futebol num mundo globalizado. In Futebol e Globalização; Ribeiro, L., Ed.; Fontoura: Jundiaí, Brazil, 2007.

10. Meneses, G.A.; Avalos González, J.M. La investigación del futbol y sus nexos con los estudios de comunicación: Aproximaciones y ejemplos. Comunicación y Sociedad 2013, 20, 33-64.

11. De Sousa, A.L.N.; Cervi, L. Video activism in the Brazilian protests: genres, narratives and political participation. Northern Lights 2017, 15, 69-88. [CrossRef]

12. Solberg, H.Y.; Helland, K. Sports Broadcasting. Nord. Rev. 2011, 32, 17-33. [CrossRef]

13. Boyle, R.; Haynes, R. Sport, the Media and Strategic Communications Management; Routledge: London, UK, 2011.

14. Wu, J.; Guo, S.; Huang, H.; Liu, W.; Xiang, Y. Information and Communications Technologies for Sustainable Development Goals: State-of-the-Art, Needs and Perspectives. IEEE Commun. Surv. Tutor. 2018, 20, 2389-2406. [CrossRef]

15. Zuppo Colrain, M. Defining ICT in a Boundaryless World: The Development of a Working Hierarchy. Int. J. Manag. Inf. Technol. 2012, 4, 13. [CrossRef]

16. Ioakimidis, M. Online marketing of professional sports clubs: Engaging fans on a new playing field. Int. J. Sports Mark. Spons. 2010, 11, 2-13. [CrossRef]

17. Araujo, N.; De Carlos, P.; Fraiz, J.A. Top European football clubs and social networks: A true 2.0 relationship? Sport Bus. Manag. Int. J. 2014, 4, 250-264. [CrossRef]

18. Baena, V. Getting Brand Commitment through Internet and Mobile Sports Marketing. In Handbook of Research on Digital Marketing Innovations in Social Entrepreneurship and Solidarity Economics; IGI Global: Hershey, PA, USA, 2014; pp. 203-218.

19. Nisar, T.M.; Prabhakar, G.; Patil, P.P. Patil, Sports clubs' use of social media to increase spectator interest. Int. J. Inf. Manag. 2018, 43, 188-195. [CrossRef]

20. Lopezosa, C.; Codina, L.; Rovira, C. Visibilidad Web de Portales de Televisión y Radio en España: ¿qué Medios Llevan a Cabo un Mejor Posicionamiento en Buscadores? Serie DigiDoc-EPI, n; Ediciones Profesionales de la Información SL.: Barcelona, Spain, 2019; ISBN 978-84-09-07716-8.

21. Ellcessor, E. Captions On, Off, on TV, Online: Accessibility and Search Engine Optimization in Online Closed Captioning. Telev. New Media 2012, 13, 329-352. [CrossRef]

22. Codina, L.; Iglesias-García, M.; Pedraza, R.; García-Carretero, L. Visibilidad y Posicionamiento Web de Informaciones Periodísticas: El Framework SEO-RCP; Serie Editorial DigiDoc-UPF: Barcelona, Spain, 2016; Available online: http://repositori.upf.edu/handle/10230/26040 (accessed on 22 February 2019).

23. Giomelakis, D.; Veglis, A. Investigating Search Engine Optimization Factors in Media Websites, The case of Greece. Digit. J. 2016, 4, 379-400. [CrossRef]

24. Costa-Sánchez, C.; Guarinos, V. Gestión de marca corporativa online de los canales públicos de televisión en Europa. Propuesta de indicadores para su medición. Revista Latina de Comunicación Social 2018, 73, 895-910.

25. Yoshida, M.; Gordon, B.; Nakazawa, M.; Biscaia, R. Conceptualization and Measurement of Fan Engagement: Empirical Evidence from a Professional Sport Context. J. Manag. 2014, 28, 399-417. [CrossRef]

26. Baena, V. Analyzing online and mobile marketing strategies as brand love drivers in sports teams. Findings from Real Madrid. Int. J. Sports Mark. Spons. 2016, 17, 202-218. [CrossRef]

27. Dunning, E. Sport et Civilisation. La Violence Maîtrisée; Fayard: Paris, France, 1994.

28. Giulianotti, R. Fanáticos, seguidores, fas e flaneurs: Uma taxonomia do identidades do torcedor no futebol. Recorde Revista de História do Esporte 2012, 5, 123-190.

29. Akbal, E.; Güneş, F.; Akbal, A. Digital Forensic Analyses of Web Browser Records. J. Softw. 2016, 11, 631-637. [CrossRef]

30. Bordieu, P. Deporte y Clase Social. In Materiales de Sociología del Deporte; La Piqueta: Madrid, Spain, 1993.

31. Hobsbawm, E.J. Naciones y Nacionalismo Desde Crítica; Grijaldo Mondadori: Barcelona, Spain, 1992.

32. Roversi, A. Calcio e Violenza in Europa; Il Mulino: Bologna, Italy, 1990.

33. Bale, J. Playing at home: British football and a sense of place. In British Football and Social Change: Getting into Europe; Williams, J., Wagg, S., Eds.; Leicester University Press: Leicester, UK, 1991.

34. Moragas, M. El Impacto de Internet en Los Medios de Comunicación y la Industria del Deporte; Centre d'Estudis Olímpics, Bellaterra Universitat Autònoma de Barcelona: Barcelona, Spain, 2003. 
35. Roberts, K. Lovemarks: The Future Beyond Brands. Power House Books: New York, NY, USA, 2005. Available online: https://s3.amazonaws.com/academia.edu.documents/44012240/LoveMarks.pdf?AWSAccessKeyId= AKIAIWOWYYGZ2Y53UL3A\&Expires=1556514093\&Signature=tcIoir96Ef8zeCnSTvQmC28nVlc\% 3D\&response-content-disposition=inline \%3B\%20filename\%3DTHE_FUTURE_BEYOND_BRANDS.pdf (accessed on 29 April 2019).

36. Soriano, F. La Pilota No Entra Per Atzar; Ara llibres: Badalona, Italy, 2009.

37. Kiruthika, J.; Greenhill, D.; Francik, J.; Khaddaj, S. User Experience Design in Web Applications. In Proceedings of the 2016 IEEE Intl Conference on Computational Science and Engineering (CSE) and IEEE Intl Conference on Embedded and Ubiquitous Computing (EUC) and 15th Intl Symposium on Distributed Computing and Applications for Business Engineering (DCABES), Paris, France, 24-26 August 2016; pp. 642-646.

38. Costa, C.; Piñeiro, T. Estrategias de Comunicación Multimedia; Editorial UOC: Barcelona, Spain, 2013.

39. McLuhan, M.; Nevitt, B. Take Today: The Executive as Dropout; Harcourt Brace Jovanovich: New York, NY, USA, 1972.

40. Levine, R.; Locke, C.; Searls, D.; Weinberger, D. The Cluetrain Manifesto. 1999. Available online: http://www.cluetrain.com (accessed on 21 January 2012).

41. Tejedor, S. La Enseñanza del Ciberperiodismo en Las Licenciaturas de Periodismo de España; Universitat Autònoma de Barcelona: Barcelona, Spain, 2006.

42. Rincón Quintero, Y.R. Vinculación de relaciones públicas, comunicación corporativa, y logística en la organización. Revista Encuentros Universidad Autónoma del Caribe 2014, 12, 47-59.

43. Chiou, W.-C.; Lin, C.-C.; Perng, C. A strategic framework for website evaluation based on a review of the literature from 1995-2006. Inf. Manag. 2010, 47, 282-290. [CrossRef]

44. UEFA. Club Licensing Benchmarking Report Financial Year. 2016. Available online: https://www.uefa.com/MultimediaFiles/Download/OfficialDocument/uefaorg/Clublicensing/02/53/ 00/22/2530022_DOWNLOAD.pdf (accessed on 7 October 2018).

45. Rodríguez-Martínez, R.; Codina, L.; Pedraza-Jiménez, R. Rafael Indicadores para la evaluación de la calidad en cibermedios: Análisis de la interacción y de la adopción de la Web 2. Revista Española de Documentación Científica 2012, 35, 61-93. [CrossRef]

46. George, P. Landow, Hypertext 3.0: Critical Theory and New Media in an Era of Globalization; Johns Hopkins University Press: Baltimore, MD, USA, 2006.

(C) 2019 by the authors. Licensee MDPI, Basel, Switzerland. This article is an open access article distributed under the terms and conditions of the Creative Commons Attribution (CC BY) license (http://creativecommons.org/licenses/by/4.0/). 